\title{
Distribution of Uranium and Thorium in Dolomitic Gravel Fill and Shale Saprolite
}

D.H. Phillips ${ }^{* 1}$ and D.B. Watson ${ }^{2}$

\begin{abstract}
The submitted manuscript has been authored by a contractor of the U.S. Government under contract No. DE-AC05-96R22464. Accordingly, the U.S. Government retains a non-exclusive, royalty-free license to publish or reproduce the published form of this contribution, or allow others to do so, for U.S. Government purposes.
\end{abstract}

\footnotetext{
${ }^{\mathrm{T}}$ Environmental Engineering Research Centre, School of Planning, Architecture, and Civil Engineering, Queen's University of Belfast, Belfast BT9 5AG, Northern Ireland, Corresponding author. d.phillips@qub.ac.uk,

${ }^{2}$ Environmental Sciences Division, Oak Ridge National Laboratory, P.O. Box 2008, Oak Ridge, Tennessee 37831.
} 


\begin{abstract}
The objectives of this study were to examine 1) the distribution of $U$ and Th in dolomitic gravel fill and shale saprolite, and 2) the removal of uranium from acidic groundwater by dolomitic gravel through precipitation with amorphous basaluminite at the U.S. DOE Oak Ridge Integrated Field Research Challenge (ORIFRC) field site west of the Oak Ridge Y-12 National Security Complex in East Tennessee. Media reactivity and sustainability are a technical concern with the deployment of any subsurface reactive media. Because the gravel was placed in the subsurface and exposed to contaminated groundwater for over 20 years, it provided a unique opportunity to study the solid and water phase geochemical conditions within the media after this length of exposure. This study illustrates that dolomite gravel can remove $\mathrm{U}$ from acidic contaminated groundwater with high levels of $\mathrm{Al}^{3+}, \mathrm{Ca}^{2+}, \mathrm{NO}^{3-}$, and $\mathrm{SO}_{4}{ }^{2-}$ over the long term. As the groundwater flows through high $\mathrm{pH}$ carbonate gravel, $\mathrm{U}$ containing amorphous basaluminite precipitates as the $\mathrm{pH}$ increases. This is due to an increase in groundwater $\mathrm{pH}$ from 3.2 to $\sim 6.5$ as it comes in contact with the gravel. Therefore, carbonate gravel could be considered as a possible treatment medium for removal and sequestration of $U$ and other $\mathrm{pH}$ sensitive metals from acidic contaminated groundwater. Thorium concentrations are also high in the carbonate gravel. Thorium generally shows an inverse relationship with $U$ from the surface down into the deeper saprolite. Barite precipitated in the shallow saprolite directly below the dolomitic gravel from barium present in the acidic contaminated groundwater.
\end{abstract}

Key words: uranium, thorium, amorphous basaluminite, barite, groundwater contamination, Oak Ridge Integrated Field Research Challenge (ORIFRC) 


\subsection{INTRODUCTION}

Contamination of the environment by radionuclides, especially uranium and its decay products, is a global problem [1-3]. Large amounts of radionuclides are present on US Department of Energy complexes due to the development of nuclear weapons during the Cold War. Subsurface contamination from U and other contaminants at the Y-12 National Security Complex on the DOE Oak Ridge Reservation (ORR), Tennessee are a result of radionuclides being released into the geological material from uranium production activities between 1945 to 1985 [4]. Between 1951 and 1984, high ionic strength nitric acid wastes containing uranium, technetium-99, metals, nitrate, and tetrachloroethylene were disposed of in 4 unlined ponds (S-3 ponds) on the Y-12 Complex which are now capped with a parking lot [5]. A large mixed waste plume of contaminated groundwater is preferentially migrating away from the ponds towards nearby Bear Creek [5-8]. Rates and mechanisms of immobilization and natural attenuation of metals, radionuclides (i.e., U, Th) and co-contaminants like nitrate are being studied at the U.S. DOE Oak Ridge Integrated Field Research Challenge (ORIFRC) field site located near the S-3 ponds [7-10]. Therefore, it is important to investigate precipitation and adsorption of $U$ and its relationship with other contaminants (i.e. Th, nitrate) within the subsurface geological material in order to understand and model the fate and transport of $U$ at the site.

Phillips et al. [11] report that dolomitic gravel on the ORIFRC site has been exposed to acidic ( $\mathrm{pH}$ 3.4) groundwater contaminated with $\mathrm{U}\left(40 \mathrm{mg} \mathrm{L}^{-1}\right), \mathrm{NO}_{3}{ }^{-}(14,000$ $\left.\mathrm{mg} \mathrm{L}^{-1}\right)$ and $\mathrm{Al}^{3+}\left(900 \mathrm{mg} \mathrm{L}^{-1}\right)$. U precipitates occur as white to light yellow crackedcoatings on this gravel $(2 \mathrm{~mm}-5 \mathrm{~cm})$ and as individual precipitates within the fine matrix 
$(<2 \mathrm{~mm})$ of the gravel. These precipitates are associated with amorphous basaluminite $\left[\mathrm{Al}_{4}\left(\mathrm{SO}_{4}\right)(\mathrm{OH})_{10} \cdot 4 \mathrm{H}_{2} \mathrm{O}\right]$ and fluoresce a bright green under ultraviolet (UV) short-wave light. U concentrations range from 1.6-19.8\% (7\% average) in the coatings with higher amounts at the dolomite interface according to SEM microprobe analysis. The $\mathrm{U}$ is hexavalent according to X-ray absorption near edge structure spectroscopy (XANES), and uranyl is coordinated by carbonate as shown by extended X-ray absorption fine structure spectroscopy (EXAFS). Some of these uranyl carbonates are best described by a split $\mathrm{K}^{+}$-like shell similar to grimselite $\mathrm{K}_{4} \mathrm{Na}\left(\mathrm{UO}_{2}\left(\mathrm{CO}_{3}\right)_{3}\right) \cdot \mathrm{H}_{2} \mathrm{O}$, while others are better described by a single $\mathrm{Ca}^{2+}$-like shell similar to liebigite $\left[\mathrm{Ca}_{2}\left(\mathrm{UO}_{2}\right)\left(\mathrm{CO}_{3}\right)_{3} \cdot 11\left(\mathrm{H}_{2} \mathrm{O}\right)\right]$ or andersonite $\left[\mathrm{Na}_{2} \mathrm{CaUO}_{2}\left(\mathrm{CO}_{3}\right)_{3} \cdot 6 \mathrm{H}_{2} \mathrm{O}\right]$. Microprobe analysis of the dolomitic gravel showed Ca present at an average of $1.5 \%$ (range of 1.0-5.7\%) in the precipitates [11].

$\mathrm{Gu}$ et al. [12] reported co-precipitation of $U$ with mixed solid phases of amorphous $\mathrm{Al}$ hydroxides and $\mathrm{SO}_{4}{ }^{2-}$ when ORIFRC site water with high levels of $\mathrm{U}, \mathrm{Ca}$, $\mathrm{Al}, \mathrm{NO}_{3}$, and $\mathrm{SO}_{4}{ }^{2-}$ were titrated with $\mathrm{NaOH}$ to a $\mathrm{pH} \sim 5.5$. According to Gu et al. [12], $\mathrm{U}$ generally forms uranly $\left(\mathrm{UO}_{2}{ }^{2+}\right)$ in groundwater under oxic conditions which prevails at the S-3 site. Additionally, Zhang et al. [13] developed a geochemical model to predict aqueous and solid phase concentrations of U during acid or base additions. Most U(VI) did not remain in solution at $\mathrm{pH} \sim 5$. The formation of anionic uranyl-carbonate species increased as the $\mathrm{pH}$ increased. Sorption of uranyl-carbonate in the model was in the form of $\mathrm{UO}_{2}(\mathrm{CO} 3)_{2}{ }^{2-}$ forming $\mathrm{y}_{2} \mathrm{UO}_{2}\left(\mathrm{CO}_{3}\right)_{2}$. The objectives of this study were to examine 1) the distribution of $U$ and $T h$ in dolomitic gravel, and 2) the removal of uranium from acidic groundwater by dolomitic gravel through precipitation with amorphous basaluminite on a large-scale under field conditions 20 years after placement. This study 
provided a unique opportunity to examine the solid and water phase geochemical conditions within the media after this long-term exposure.

\subsection{MATERIALS AND METHODS}

\subsection{Study Area and Geological Materials}

The cores were recovered from Area 4 at the ORIFRC site on the Y-12 National Security Complex on the ORR in Oak Ridge, Tennessee (Fig. 1). The cores were composed of a weakly developed soil (with Ap and Bw horizon) at the surface that formed over a 20-30 year period in soil material that was deposited over a gravel fill which covered the native highly weathered shale saprolite. The gravel fill is composed of dolomite fragments $(2 \mathrm{~mm}$ to $3 \mathrm{~cm})$ and fine material $(<2 \mathrm{~mm})$, and probably excavated from the nearby Upper Cambrian Copper Ridge Dolomite of the Knox Group found in Rogers Group Quarry in Union Valley, Tennessee. The native shallow saprolite found at the site was excavated in 1983 and backfilled with the gravel to about $4 \mathrm{~m}$ deep to serve as a base for large storage tanks. This highly permeable gravel fill is about $60 \mathrm{~m}$ from the S-3 Ponds and intercepts roughly the top meter of the groundwater plume redirecting groundwater contaminants in the direction of Bear Creek (Fig. 1). This gray (10YR 6/1) gravel fill, extends from the surface down to 90 inches $(228.6 \mathrm{~cm})$ where it rests on top of shale saprolite that has resulted from the weathering of the Middle to Late Cambrian Conansauga Group Nolichucky Shale formation [14].

\subsection{Sample Collection, Preparation and Descriptions}


The sections of the two undisturbed continuous cores $(2.5 \%$ diameter $)(6.35 \mathrm{~cm})$ that are used in this study were sampled at the depths of $0-800 \mathrm{~cm}(\mathrm{FWB} 408)$ and $269 \mathrm{~cm}$ (top of water table) to $847 \mathrm{~cm}$ (FWB410), by a pneumatic hammer-drive coring devise by driving the corer containing a polyurethane tube through a hollow barrel into the geological material. Core material was described according to Soil Survey Division Staff [15]. The samples were air dried in order to be analyzed in accordance to standard procedures. Drying may have resulted in some small chemical changes, however, the water table fluctuates at this site, and at times, especially during the summer droughts, the gravel could be dry in the zone which contains the high concentrations of U. Therefore, air drying should not cause a change in the sample beyond natural field conditions. The solid phase material also contains an estimated 90,000 times more $U$ than the groundwater in the pores; therefore, evaporation of whatever groundwater is present would have an inconsequential impact on the total uranium content on the solid phase. The coarse gravel $(>2 \mathrm{~mm})$ was separated from fine material $(<2 \mathrm{~mm})$ using a $2 \mathrm{~mm}$ mesh sieve. Additionally, the white to light yellow coatings were also gently scraped off the dolomite gravel and added to the $<2 \mathrm{~mm}$ fraction (Fig. 2a, b). Selected coatings were collected for SEM analysis (Fig. 2c-e). The $<2 \mathrm{~mm}$ fraction was gently sieved through an 80 mesh sieve to separate small dolomite grains from the very fine $(<80 \mathrm{mesh})$ material which contained the $U$ bearing precipitates [11]. The weathered saprolite was ground to pass through a $\leq 45$ micro sieve.

A multiport well was installed in FW410 with the shallow port being screened $(274-427 \mathrm{~cm})$ across the shallow gravel fill zone and the deeper port screened (722$838 \mathrm{~cm})$ in the acidic saprolite zone. 


\subsection{Microscopic Analyses}

Selected undisturbed samples of the core material were impregnated with Hilquist resin (Hilquist, Falls City, WA). After curing, the samples were ground and polished using $1 \mu \mathrm{m}, 0.6 \mu \mathrm{m}, 0.3 \mu \mathrm{m}$, and $0.1 \mu \mathrm{m}$ polishing grit (Buhler LTD, Lake Bluff, IL), carbon coated with an Agar sputter coater, and analyzed with a XL30FEG Philips SEM (Eindhoven, The Netherlands) using energy dispersive analysis (EDS) and backscatter analysis (BSE) at 10KV. SEM-wavelength dispersive spectroscopy (WDS) was carriedout by analyzing for 4 hours $\mathrm{Al}, \mathrm{Mg}, \mathrm{S}, \mathrm{U}, \mathrm{Th}$, and $\mathrm{Ca}$ in selected areas of the polished section of the uranium containing dolomite gravel.

\subsection{Core Material Geochemical Analysis}

Uranium and Th concentrations in soil samples were assayed using gamma-ray spectroscopy employing $20 \mathrm{~g}$ of air-dried soil (or less when the quantity was limited) contained in a standard $20 \mathrm{~mL}$ polypropylene scintillation vial. Routine counting times of $60 \mathrm{~min}$ were employed using a $7.62 \mathrm{~cm}$ diameter $\times 7.62 \mathrm{~cm}$ high well-type NaI crystal with a multi-channel analyzer employing Accuspec $®$ Y-spectroscopy software (Canberra Industries) and an automatic sample changer. Whole-spectrum stripping, after subtracting the instrument's background spectrum which was collected using an empty vial, was employed using a best-fit fractional combination of three standard spectra $\left({ }^{238} \mathrm{U}\right.$, ${ }^{232} \mathrm{Th}$ ). Standard spectra of these two radionuclides were collected using standard solutions of uranium (Spex Certiprep Inc), and thorium (J.T. Baker). Linear combinations of these three standard spectra accounted for $>99 \%$ of the measured counts indicating no 
significant content of other $\mathrm{Y}$-emitting radionuclides in these soils. Results were

expressed as mass of each element per unit weight of air-dried soil (i.e., $\mu \mathrm{g} \mathrm{g}^{-1}$ ) to be directly comparable with other analytical methods.

The $\mathrm{pH}$ of the samples was measured using a 1:1 sample:MQ water mixture. The mixture was placed on a box shaker for 30 minutes, and then centrifuged at $2100 \mathrm{rpm}$ for 15 minutes. Total sulfur $\left(\mathrm{S}_{\mathrm{t}}\right)$ was determined by combustion using a Leco total $\mathrm{C}, \mathrm{N}, \mathrm{S}$ analyzer (Leco Corp. St. Joseph MI). Sodium citrate bicarbonate dithionite (CBD) solution extracts both the crystalline and poorly crystalline (amorphous) Al oxides [16], while the ammonium oxalate (AO) solution extracts the poorly crystalline (amorphous) $\mathrm{Al}$ oxides [17]. Poorly crystalline $\mathrm{Al}$ oxides $\left(\mathrm{Al}_{\mathrm{o}}\right)$ were extracted by shaking in the dark for 2 hours $\sim 0.5$ gr of core material in $30 \mathrm{mls} 0.2 \mathrm{M}$ AO solution buffered to $\mathrm{pH} 3.0$ [17]. Free $\mathrm{Al}$ oxides $\left(\mathrm{Al}_{\mathrm{d}}\right)$ were extracted by shaking over-night $\sim 2.0$ gr of core material in 24 $\mathrm{ml}$ of $0.3 \mathrm{M} \mathrm{CBD}$ solution until the material changed to a gray color (generally 3 times) [16]. Uranium was also extracted with the AO solution $\left(\mathrm{U}_{\mathrm{o}}\right)$ and $\mathrm{CBD}$ solution $\left(\mathrm{U}_{\mathrm{d}}\right)$. After centrifuging at $2100 \mathrm{rpm}$ for $15 \mathrm{~min}$, these oxides were analyzed using a Perkin Elmer Elan 5000 inductively coupled plasma Mass Spectrometer (Franklin, MA).

\subsection{RESULTS AND DISCUSSION}

\subsection{Distribution of $U$ and $T h$ in Amorphous Basaluminite Precipitates in Dolomitic Gravel}

From the surface down to the water table (0 to $228.6 \mathrm{~cm}$ ) in FW408, total U ranges from $19-68 \mathrm{mg} \mathrm{kg}^{-1}$ in the poorly developed soil and uncoated dolomitic gravel (Fig. 3). However, there is a dramatic increase in $\mathrm{U}$ below the zone of water table 
fluctuation, where bulk samples from FWB408 have a maximum gross gamma activity of 70 cps. The $\mathrm{U}$ is present in amorphous basaluminite $\left[\mathrm{Al}_{4}\left(\mathrm{SO}_{4}\right)(\mathrm{OH})_{10} \cdot 4 \mathrm{H}_{2} \mathrm{O}\right]$ precipitates which occur and coat in between the gravel fragments from the interface of the water table down to the underlying shale saprolite. Similar cracked coatings have been observed as basaluminite precipitates on limestone grains which were used to increase $\mathrm{pH}$ on a pyrite tailings site [18].

In the upper section of the amorphous basaluminite precipitation zone, fine material in a wet brown gray gravel (10YR 5/2) has $\mathrm{U}_{\mathrm{t}}$ concentrations as high as 7,508 $\mathrm{mg} \mathrm{kg}^{-1}$ and 8,094 $\mathrm{mg} \mathrm{kg}^{-1}$ in cores FWB408 and FWB410, respectively (Figs. 3, 4). However, in the lower portion directly below the brown grey gravel, there is an increase in fine material and associated white to light yellow precipitates (10YR 7/2) that strongly fluoresce a light green (Fig. 2a) due to high $U$ content [11]. In this section, $U_{t}$ peaks at $12,730 \mathrm{mg} \mathrm{kg}^{-1}$ in FWB410 and $10,188 \mathrm{mg} \mathrm{kg}^{-1}$ in FWB408. At the depths of 295-305 cm in core FWB410, some areas of the coatings showed a much stronger fluorescence (Fig. 2a). These coatings with a high fluorescence were analyzed separately from the bulk coating samples and averaged $66,500 \mathrm{mg} \mathrm{kg}^{-1} \mathrm{U}$.

The underlying saprolite has a dramaticly lower $U$ content $\left(\sim 50-200 \mathrm{mg} \mathrm{kg}^{-1}\right)$ to the depths of $8 \mathrm{~m}$ (Fig. 3). The source of the $\mathrm{U}$ is a shallow acidic ( $\mathrm{pH} \sim 3.2) \mathrm{U}$ contaminated groundwater plume flowing to the west from the S-3 ponds source area [6] into Area 4. Because the gravel fill in Area 4 has a higher permeability than the underlying clayey saprolite, it acts as a preferred groundwater transport pathway causing the acidic groundwater plume to enter and react within the higher $\mathrm{pH}$ gravel. 
Thorium is also present and was generally lower in concentration compared to $\mathrm{U}$ (Figs 3, 4). However, Th concentrations were higher in the gravel layer above the water table where U concentrations were low. Thorium concentrations fluctuated dramatically in the gravel below the water table where $U$ was highest, and showed an almost inverse relationship with $U$. In some places, Th was higher than $U$ in this zone. These large changes in Th concentrations are observed over short intervals in these gravel zone. Figure 5 shows the images of $\mathrm{U}$ is associated with precipitates and not the gravel matrix. Thorium on the other hand is spread throughout the precipitates and gravel matrix suggesting more of a sorption mechanism for attachment to the solid phase.

\subsection{Composition of Uranium Containing Precipitates}

As the acidic U contaminated groundwater enters the dolomitic gravel fill ( 229 $325 \mathrm{~cm}$ depth interval), hexavalent uranyl carbonate coprecipitated with amorphous basaluminite (Fig. 2a-c) which is composed of $\mathrm{Al}$ (hydr)oxides and $\mathrm{SO}_{4}{ }^{2-}$. Historical sampling from well FW410-14 located in the gravel has detected values for calcium of 105-150 mg/L, inorganic carbon (IC) of 50-108 mg/L, $\mathrm{pH}$ of 6.2-6.7 and $\mathrm{U}$ of $0.7-1.3$

$\mathrm{mg} / \mathrm{L}$. The deeper well, FW410-28, screened in the underlying saprolite has a much lower $\mathrm{pH}$ of 3.2-3.4 and calcium of 100-476, IC of 34-114 and U of 20-40 mg/L. The U dissolved in groundwater in the gravel, although much lower than in the underlying acidic saprolite, is probably in a relatively stable and a mobile calcium-uraniumcarbonate complex. Although solid phase carbonate was not directly measured in the gravel samples, it is expected to be of a high concentration due to the gravel material being primarily composed of dolomite $\left[\mathrm{CaMg}\left(\mathrm{CO}_{3}\right)_{2}\right]$ fragments which has been 
responsible for an increased $\mathrm{pH}$ of the groundwater flowing through the gravel. The precipitation of these $\mathrm{U}$ containing formations in the gravel fill is driven by $\mathrm{pH}$ differences between the higher $\mathrm{pH}$ carbonate rich fill, which currently has a solid phase $\mathrm{pH}$ of 6.3-6.8, and the acidic groundwater plume in the saprolite (Figs 3, 4). The dolomitic gravel possibly had an even higher $\mathrm{pH}$ than this before exposure to the acidic groundwater. Groundwater $\mathrm{pH}$ in the gravel fill is $\sim 6.5-6.7$, and there is a consequent decrease in $\mathrm{U}$ to $\sim 1.0 \mathrm{mg} \mathrm{L}^{-1}$, compared to the deeper port of FW410 screened in the saprolite where groundwater $\mathrm{pH}$ is 3.23 and $\mathrm{U}$ content is $40 \mathrm{mg} \mathrm{L}^{-1}$. Although the concentration of $U$ in groundwater found in the gravel fill is lower, the form of $U$ has changed to a $\mathrm{U}$ carbonate form that is more mobile compared to the $\mathrm{U}$ forms in the underlying saprolite $[11,19]$. In alkaline conditions, carbonate is a strong ligand that can significantly control the mobility of U(VI) in groundwater by forming uranyl-carbonate complexes. These complexes are generally weakly sorbed to mineral surfaces [20,21]. Similarly, Zhang et al. [22] and Luo [23] reported that U(VI) was effectively sequestered from acidic groundwater when the $\mathrm{pH}$ was increased from 3.5 to 4.4 and $\mathrm{pH}>4.5$, respectively, by slow titration of $\mathrm{NaOH}$. U(VI) sequestration in the Zhang et al. [22] study was due to sorption on $\mathrm{pH}$-dependent surface charge sites on Al hydroxides. The positively charged surface on the precipitated Al minerals could provide sites for anionic $\mathrm{U}$, carbonate and sulfate sorption [22]. A similar mechanism may have also occurred in the dolomitic gravel at the ORIFRC site. Additionally, Luo et al. [23] showed that U can be immobilized even under low carbonate concentrations if a low carbonate concentration and relatively high $\mathrm{pH}(>5)$ are maintained in sediments [23]. 
The high level of $\mathrm{Al}$ in the precipitates (Fig. 5a,b) is also attributed to the $\mathrm{Al}$ in groundwater. Aluminum groundwater concentrations follow the same trend as the $\mathrm{U}$ groundwater concentrations, with Al concentrations at $2.9 \mathrm{mg} \mathrm{L}^{-1}$ in the shallow port of FW410 compared to $883 \mathrm{mg} \mathrm{L}^{-1}$ in the deep port [11]. The presence of $\mathrm{S}$ (Fig. 5a,b) is due to the sulfate found in the groundwater plume from the S-3 ponds (high sulfate is generally present in groundwater where there is high $U$ ) and the weathering of pyrite $\left(\mathrm{FeS}_{2}\right)$ inclusions in the dolomitic fragments (Fig. 2d). Modeling of the groundwater data showed a correlation of the $\mathrm{S}$ in the coatings and the release of $\mathrm{S}$ during the weathering of the pyrite in the dolomitic fragments [24]. Tang et al.[25] observed a slow pH increase as a result of strong buffering by $\mathrm{Al}$ precipitation and hydrolysis and $\mathrm{CO}_{2}$ uptake in a study to develop a model to better predict U(VI) sequestration in acidic U contaminated sediment with high $\mathrm{Al}$ concentrations. When basaluminite and amorphous $\mathrm{Al}(\mathrm{OH})_{3}$ precipitation reactions along with a cation exchange selectivity coefficient $\mathrm{K}_{\mathrm{NalAl}}$ of 0.3 were used, the model described surface complexations of $U$ with liebigite $\left(\mathrm{Ca}_{2} \mathrm{UO}_{2}\left(\mathrm{CO}_{3}\right)_{3} \cdot 10 \mathrm{H}_{2} \mathrm{O}\right)$ precipitation $(\mathrm{pH}>5)$ [25]. In an earlier study, Phillips et al [11] report that both uranyl carbonates (grimselite and liebigite) were present in precipitates from the gravel section and gravel-saprolite interface section of these cores. Uranyl carbonates with a split $\mathrm{K}^{+}$-like shell (grimselite) were detected by EXAFS adjacent to weathering rinds, perhaps as thin coatings on the surface of some of the gravel fragments where the highest concentrations of $\mathrm{U}$ and $\mathrm{K}^{+}$were observed in the coatings. The source of the $\mathrm{K}^{+}$is possibly from the $\mathrm{K}$-feldspar inclusions in the gravel. However, the thin grimselite coating was not always detected on gravel surfaces in the study, possibly due to the position and absence of K-feldspar inclusions in these gravel fragments analyzed. 
Uranyl carbonates with a single $\mathrm{Ca}^{2+}$-like shell were identified throughout coatings on the dolomitic gravel fragments from the gravel-saprolite interface.

Total $\mathrm{U}\left(\mathrm{U}_{\mathrm{t}}\right)$ concentrations were higher than $\mathrm{U}_{\mathrm{o}}$ and $\mathrm{U}_{\mathrm{d}}$ concentrations in the dolomitic gravel fill (Figs 3, 4, 6). The uranyl carbonates present in the amorphous basaluminite are possibly in a form that is not extractable or only partially extractable by $\mathrm{CBD}$ and $\mathrm{AO}$ solutions which are designed to extract crystalline and amorphous oxides and amorphous oxides, respectively. Additionally, $\mathrm{U}_{\mathrm{o}}$ values were generally higher than $\mathrm{U}_{\mathrm{d}}$ values because the coatings contained higher amounts of amorphous $\mathrm{Al}$ oxide compared to crystalline $\mathrm{Al}$ oxide. In the $\mathrm{U}$-enriched gravel zone of $\mathrm{FW} 408, \mathrm{Al}_{\mathrm{o}}$ content is high and ranges from 14,542 to $75,327 \mathrm{mg} \mathrm{kg}^{-1}$. There was high correlation between $\mathrm{Al}_{\mathrm{o}}$ and $\mathrm{U}_{\mathrm{o}}$ in FW408 $\left(\mathrm{r}^{2}=0.99\right)$ and FW410 $\left(\mathrm{r}^{2}=0.97\right)$ in the U-rich amorphous basaluminite (Fig 7). $\mathrm{Al}_{\mathrm{d}}$ ranged from $270 \mathrm{mg} \mathrm{kg}^{-1}$ in the overlying low $\mathrm{U}$ content gravel to $20,836 \mathrm{mg} \mathrm{kg}^{-1}$ in the $\mathrm{U}$ enriched gravel zone in cores FW408 and FW410 (Fig. 6). Additionally, there the correlations were high between $\mathrm{Al}_{\mathrm{d}}$ and $\mathrm{U}_{\mathrm{d}}$ for $\mathrm{FW} 408\left(\mathrm{r}^{2}=0.71\right)$ and FW410 $\left(\mathrm{r}^{2}=0.95\right)$ in this zone, but they were not as well correlated as the $\mathrm{Al}_{\mathrm{o}}$ and $\mathrm{U}_{\mathrm{o}}$ values for FW408. This is due to the extractable $\mathrm{U}$ being more associated with the amorphous $\mathrm{Al}$ than the crystalline $\mathrm{Al}$ in the basaluminite coatings. There was good correlation $\left(\mathrm{r}^{2}=0.63\right)$ between $\mathrm{Al}_{\mathrm{d}}$ and $\mathrm{Al}_{\mathrm{o}}$ in the gravel zone of FW408, but less correlation in FW410 $\left(\mathrm{r}^{2}=0.49\right)$. The gravel zone in FW408 appears to have more amorphous $\mathrm{Al}$, and uranium appears to be associated with this precipitate compared to that in FW410.

\subsection{Saprolite below the Gravel}


The saprolite is a highly weathered, oxidized (7.5YR 5/6) clayey Nolichucky shale with areas of gleying (10YR 7/1) [5] indicating hydromorphic conditions from the water table at the interface of saprolite and gravel. The upper $5 \mathrm{~cm}$ of saprolite is mixed with the gravel where the $U_{t}$ concentrations are 52-7,602 $\mathrm{mg} \mathrm{kg}^{-1}$ (Figs. 3, 4). Uraniumrich coatings flake off the dolomite gravel and mix with the saprolite. The saprolite below the mixed zone has $U$ concentrations that range from $8-219 \mathrm{mg} \mathrm{kg}^{-1}$, and because the saprolite is differentially weathered interbedded shale and sandstone, the $\mathrm{U}$ concentrations vary. However, there appears to be marked reductions of $U$ at the top of main zones within the saprolite at $481 \mathrm{~cm}, 617 \mathrm{~cm}$ and $681 \mathrm{~cm}$. The $\mathrm{pH}$ of the saprolite gradually decreases with depth. The $\mathrm{pH}$ is $4.4-5.9$ in the top $10 \mathrm{~cm}$ of the saprolite in FWBs 408 and 410, however, it decreases to below 4 at about $500 \mathrm{~cm}$. These low pHs are partially responsible for the lower $U$ concentrations in the saprolite compared to the overlying dolomitic gravel. However, Phillips et al. [5, 14] report U content in the weathered bedrock in Areas 1 and 3 of the ORIFRC site near the S-3 ponds in the range of $10-750 \mathrm{mg} \mathrm{kg}^{-1}$ at $\mathrm{pH}<4$ in preferred pathway high transport zones near the bedrock interface.

Barium from the contaminated groundwater has precipitated with $\mathrm{SO}_{4}{ }^{2-}$ to form barite $\left(\mathrm{BaSO}_{4}{ }^{2-}\right)$ in the upper section of the saprolite (Fig. 2e). Citrate bicarbonate dithionite extractable $\mathrm{Ba}\left(\mathrm{Ba}_{\mathrm{d}}\right)$ ranged from 11.62 to $49.75 \mathrm{mg} \mathrm{kg}^{-1}$ in the samples from FWB408 and 410. Barium has been removed from the shallow groundwater at $427 \mathrm{~cm}$, where it is only $0.11 \mathrm{mg} \mathrm{L}^{-1}$ at a $\mathrm{pH}$ of 5.9 compared to $37 \mathrm{mg} \mathrm{L}^{-1}$ at $853 \mathrm{~cm}$ at a $\mathrm{pH}$ of 3.2. $B a_{d}$ was correlated with $S_{t}\left(r^{2}=0.67\right)$ in FWB410, but showed poor correlation in samples from FWB 408. Kersten et al. [26] and Carbonell et al. [27] report the 
precipitation of barite in alkaline conditions and Carbonell et al. [27] also noted it in anaerobic conditions. Under low $\mathrm{pH}$ and highly anaerobic environments $\mathrm{Ba}$ is released from barite.

Generally, Th was lower in concentration and inversely related to $U$ in the weathered saprolite below the gravel layer. Changes in concentrations of Th in the saprolite appeared to be related to interbedding of different geologic materials (i.e. shale and sandstone). The uranium tends to be associated with the higher permeability transport pathways as observed by Phillips et al. [5] who reported that U was highest in groundwater and geological material in the more fractured interbedded shale and sandstone in Area 3, however, this relationship was not observed with Th.

\subsection{CONCLUSIONS}

The results of the investigation provided the following conclusions:

- As highly acidic radioactive contaminated groundwater flows from the S-3 ponds site through the dolomitic gravel, $\mathrm{U}, \mathrm{Al}$, and $\mathrm{SO}_{4}{ }^{2-}$ precipitate on the surfaces of the gravel and within pore spaces removing most of the $U$ from the groundwater. These formations are in the form of flakey, white to yellowish U-containing amorphous basaluminite coatings and precipitates. This is due to an increase in the $\mathrm{pH}$ of the groundwater from 3.2 to about 6.5 as it comes in contact with the gravel.

- The U-containing amorphous basaluminite forms primarily within the saturated zone of the dolomitic gravel at concentrations as high as $12,730 \mathrm{mg} \mathrm{kg}^{-1}$ total $\mathrm{U}$. 
- Amorphous $\mathrm{Al}$ is more dominate than crystalline $\mathrm{Al}$ oxide, and linear regression analysis shows that extractable $\mathrm{U}$ is associated with both forms of $\mathrm{Al}$ oxides.

$\circ$ Thorium is also as high as $3,000 \mathrm{mg} \mathrm{kg}^{-1}$ in the $\mathrm{U}$ enriched dolomitic gravel, and it generally has an inverse relationship with $U$ from the surface down into the deeper saprolite zones.

○ Barium present in the acidic contaminated groundwater precipitated as barite in the shallow saprolite directly below the dolomitic gravel.

$\circ$ This study shows that high amounts of $\mathrm{U}$ can be removed from acidic $\mathrm{Al}^{3+}$ and $\mathrm{SO}_{4}{ }^{2-}$ containing groundwaters with dolomitic gravel. However, as the coatings grow / thicken in size, less U appears to be incorporated as reported by Phillips et al. [11]. Nevertheless, the source of the $U$ has been at the site for close to 60 years and the dolomite gravel fill was emplaced over 20 years ago, and is still removing high levels of $U$ from groundwater. The thick layered nature of the coatings and decrease of $U$ on the outside suggests precipitation of $U$ containing minerals and that sorption is not the mechanism. Additional studies are needed to determine the capacity of this medium to remove $\mathrm{U}$ from groundwater and the potential for remobilization and passivation of the gravel surfaces.

\section{Acknowledgements}

This research was funded by the U.S. DOE, Office of Science, Office of Biological and Environmental Research (BER), Subsurface Biogeochemical Research Program. Oak Ridge National Laboratory is managed by UT-Battelle, LLC, for the U.S. DOE under contract DE-AC05-18 00OR22725. 


\section{REFRENCES}

1. S. Akyil, A.M. Yusof, The distribution of uranium and thorium in samples taken from different polluted marine environment . J. Hazard. Mat, 144 (2007) 564-569.

2. M. Gavrilescu, L.V. Pavel, I. Cretescu, Characterization and remediation of soils contaminated with uranium J.Hazard. Mater, 163 (2009) 475-510.

3. D,E, Crean, F,R, Livens, M. Sajih, M.C, Stennett, D. Grolimund, C,N, Borca, N.C. Hyatt, Remediation of soils contaminated with particulate depleted uranium by multi stage chemical extraction. J. Hazard Mater. 263 (2013) 382-390.

4. S.C. Brooks, Waste characteristics of the former S-3 ponds and outline of uranium chemistry relevant to NABIR Field Research Center studies. ORNLITM-2001/27, $21 \mathrm{pp}$.

5. D.H. Phillips, D.B. Watson, Y. Roh, T.L. Mehlhorn, J-W. Moon, P.M. Jardine, Distribution of uranium contamination in weathered fractured saprolite/shale and contaminated ground water, J. Environ. Qual. 35 (2006) 1715-1730.

6. D.B. Watson, W.E. Doll, T.J. Gamey, J.R. Sheehan, P.M. Jardine, Plume and lithologic profiling with surface resistivity and seismic tomography, Groundwater 43 (2005) 169-177.

7. T.M. Gihring, G. Zhang, C.C. Brandt, S.C. Brooks, J.H. Campbell, S. Carroll, C.S. Criddle, S.J. Green, P. Jardine, J.E. Kostka, K. Lowe, T.L. Mehlhorn, W. Overholt, D.B. Watson, Z.K. Yang, W.-M. Wu, C.W. Schadt. A limited microbial consortium is responsible for extended bioreduction of uranium in a contaminated aquifer, Appl. Environ. Microbiol. 77 (2011) 5955-5965.

8. D.B. Watson, W. Wu, T. Mehlhorn, G. Tang, J. Earles, K. Lowe, T. M. Gihring, G. 8. Zhang, J. Phillips, Ma. Boyanov, B. P. Spalding, C. Schadt, K. M. Kemner, C. S. Criddle, P. M. Jardine, S. C. Brooks. In Situ Bioremediation of Uranium with Emulsified Vegetable Oil as the Electron Donor Environ. Sci. Technol. 47 (2013) 6440-6448.

9. J.D. Istok, J.M. Senko, L.R. Krumholz, D. Watson, M.A. Bogle, A. Peacock, Y.J. Chang, D.C. White. In situ bioreduction of technetium and uranium in a nitratecontaminated aquifer, Environ. Sci. Technol. 38 (2004) 468-475.

10. G. Tang, D.B. Watson, W.-M. Wu, C.W. Schadt, J.C. Parker, S.C. Brooks, U(VI) Bioreduction with Emulsified Vegetable Oil as the Electron Donor - Model Application to a Field Test. Environ. Sci.Technol. 47 (2013) 3218-3225. 
11. D.H. Phillips, D.B. Watson, S.D. Kelly, D. Ravel, K.M. Kemner. Deposition of uranium precipitates in dolomitic grave fill, Environ. Sci. Technol. 42 (2008) 71047110.

12. B. Gu, S.C. Brooks, Y. Roh, P.M. Jardine, Geochemical reactions and dynamics during titration of a contaminated groundwater with high uranium, aluminum and calcium, Geochim. Cosmochim. Acta. 67 (2003) 2749-2761.

13. F. Zhang, W. Luo, J. C. Parker, B. P. Spalding, S. C. Brooks, D. B. Watson, P. M. Jardine, B. Gu, Geochemical modeling of reactions and partitioning of trace metals and radionuclides during titration of contaminated acidic sediments. Environ. Sci. Technol. 42 (2008) 8007-8013.

14. D.H. Phillips, D.B. Watson, Y. Roh, Uranium deposits in a weathered fractured saprolite/shale, Environ. Sci. Technol. 41 (2007) 7653-7660.

15. Soil Survey Division Staff, Field Book for Describing and Sampling Soils, Version 3.0, ed. P.J. Schoeneberger, Government Printing Office, (2013) 302 pp.

16. O.P. Mehra, M.L. Jackson, Iron oxide removal from soils and clays by a dithionitecitrate system buffered with sodium bicarbonate, Clays Clay Min. 7 (1960) 317-327

17. J.A. McKeague, J.H. Day, Dithionite- and oxalate extractable $\mathrm{Fe}$ and $\mathrm{Al}$ as aids in differentiating various classes of soils, Can. J. Soil Sci. 46 (1966) 13-22.

18. M. Simón, F. Martin, I. Garcia, P. Bouza, C. Dorronsoro, J. Aguilar, Interaction of limestone grains and acidic solutions from the oxidation of pyrite tailings. Environ. Pollut.135 (2005) 65-72.

19. S.D. Kelly, K.M. Kemner, J. Carley, C. Criddle, P.M. Jardine, T.L. Marsh, D. Phillips, D. Watson, W-M.Wu, Speciation of uranium in sediments before and after in situ bioreduction, Environ. Sci. Technol. 42 (2008) 1558-1564.

20. C.K.D. Hsi, D. Langmuir, D. Adsorption of uranyl onto ferric oxyhydroxides application of the surface complexation site -binding model. Geochim Cosmochim Acta 49 (1985) 1931-1941.

21. T.D. Waite, J.A. Davis, T.E. Payne, G.A. Waychunas, N. Xu, Uranium(VI) adsorption to ferrihydrite: Application of a surface complexation model. Geochim Cosmochim Acta 58 (1994) 5465-5478.

22. F. Zhang, W. Luo, J. C. Parker, S. C. Brooks, D. B. Watson, P. M. Jardine, B. Gu, Modeling uranium transport in acidic contaminated groundwater with base addition. J. Hazard. Mat. 190 (2011) 863-868.

23. W. Luo, S.D. Kelly, K.M. Kemner, D. Watson, J. Zhou, P. M. Jardine, B. Gu, 
Sequestering Uranium and Technetium through Co-Precipitation with Aluminum in a Contaminated Acidic Environment. Environ. Sci. Technol. 43 (2009) 7516-7522.

24. F. Zhang, J.C. Parker, D.B. Watson, D. Phillips, P.M. Jardine, Simulation of groundwater composition change due to deposition of uranium minerals in dolomite gravel fill, (eds) Qiang He, Shui-Long Shen. Geoenvironmental Engineering and Geotechnics. ASCE Geotechnical Special Publications 204. (2010) pp. 181-187.

25. G. Tang, W. Luo, S. Brooks, D. Watson, B. Gu, Prediction of aluminum, uranium and co-contaminants sorption and precipitation during titration of acidic sediments. Environ. Sci. Technol. 47 (2013) 5787-93.

26. M. Kersten, B. Schulz-Dobrick, T. Lichtensteiger, C.A. Johnson, Speciation of Cr in leachates of a MSWI bottom ash landfill, Environ. Sci. Technol. 32 (1998) 13981403.

27. A.A. Carbonell, R. Pulido, R.D. DeLanue, W.H. Patrick, Soluble barium in barite and phosphogypsum amended Mississippi River alluvial sediment, J. Environ. Qual. 28 (1999) 316-321. 


\section{Figure}

a

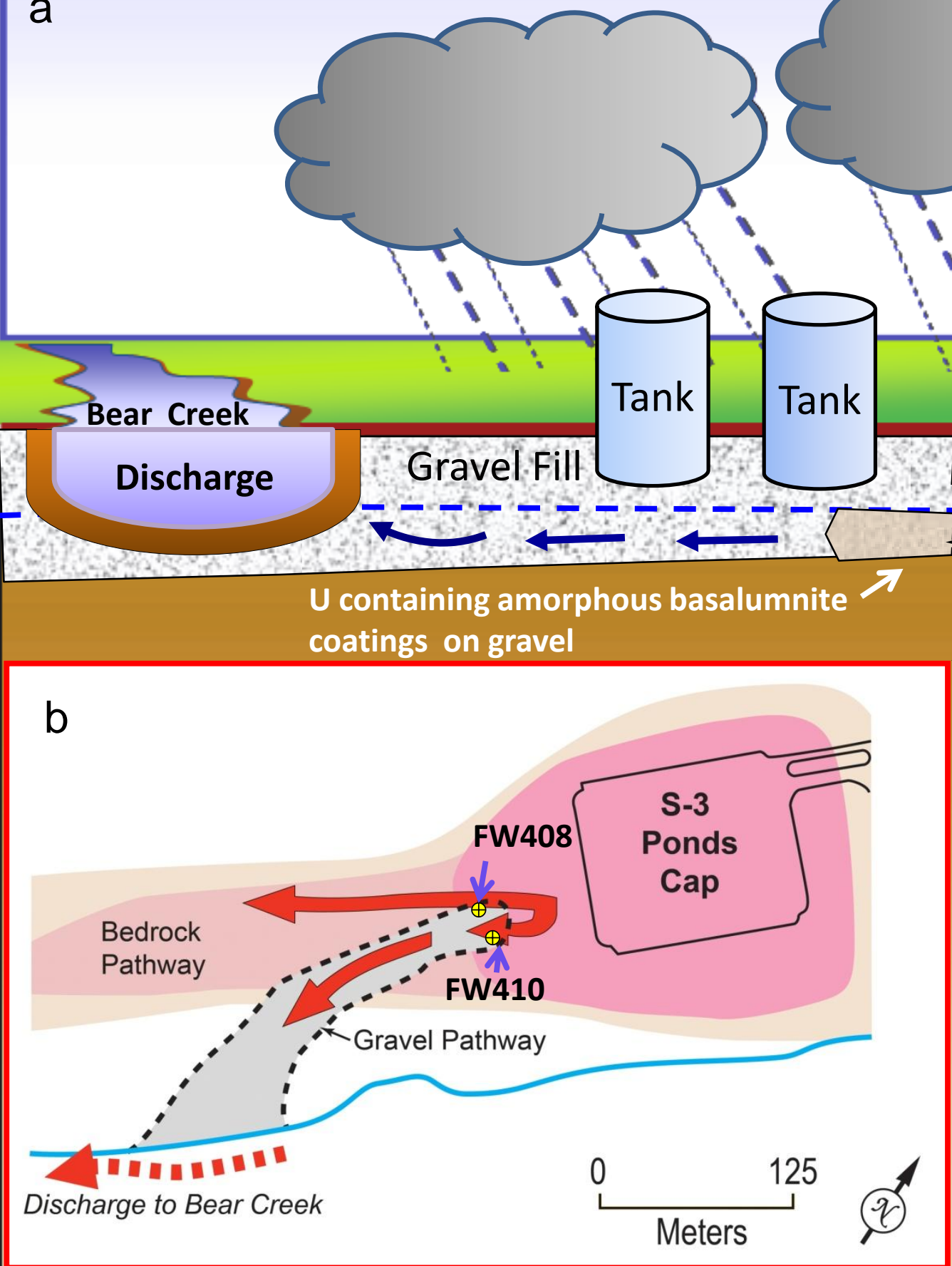

Figure 1. a) Cross-section of the FRC site showing locations of the $U$ containing amorphous basalumnite coatings in the gravel fill in relation to the source and Bear Creek, and b) aerial view of a diagram of the site showing the location of the FW 408 and FW410.

\section{Source Zone}

(S-3 Ponds)

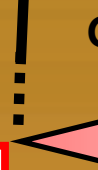

$$
\mathrm{SO}_{4}{ }^{2-} \quad \mathrm{pH}=3.2
$$

$\mathrm{Fe}$

\section{$\mathrm{Tc}(\mathrm{VII})$}




\section{$a$}


Description FW 408

Poorly developed soil in fill material

Dolomitic gravel with low $U$ content above the water table

\section{High U Zone}

Grey (10YR 6/1) dolomite gravel layer with white to light yellow (10YR 7/1) precipitates in brown grey (10YR 5/2) fine material

\section{Mixed zone of highly} weathered clayey oxidized saprolite and dolomitic gravel; Barite precipitation

Highly weathered clayey oxidized interbedded shale and sandstone saprolite (7.5YR 5/6) with areas of gleying (10YR 7/1);

Highly weathered saprolite with gleyed (5YR 6/3) shale and oxidized sandstone interbeds; clay banding; less $i$ weathered than above

Interbedded shale and sandstone saprolite with less weathering than above; Fe oxide coatings
1

10

100

1000

10000

0

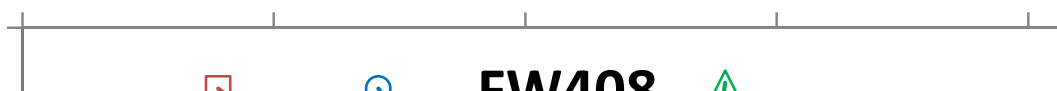

100

300

200
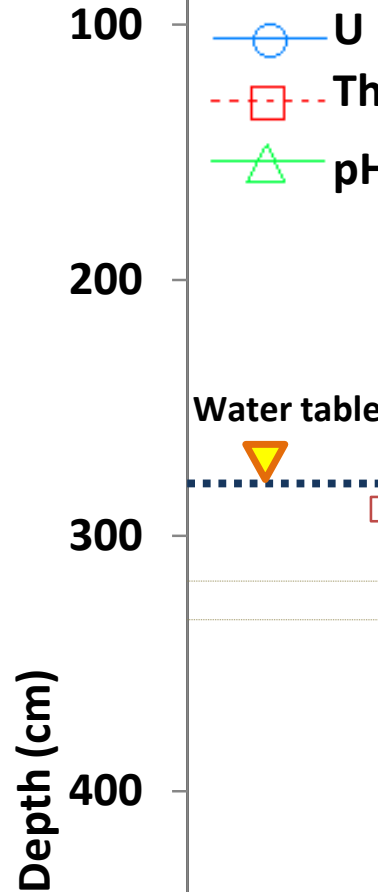

- - - . Th

$\triangle \mathbf{p H}$
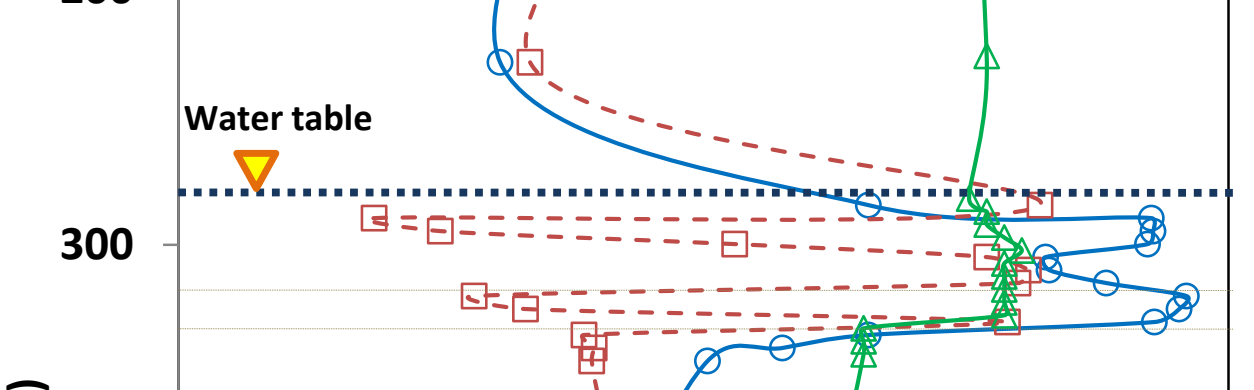

500

600

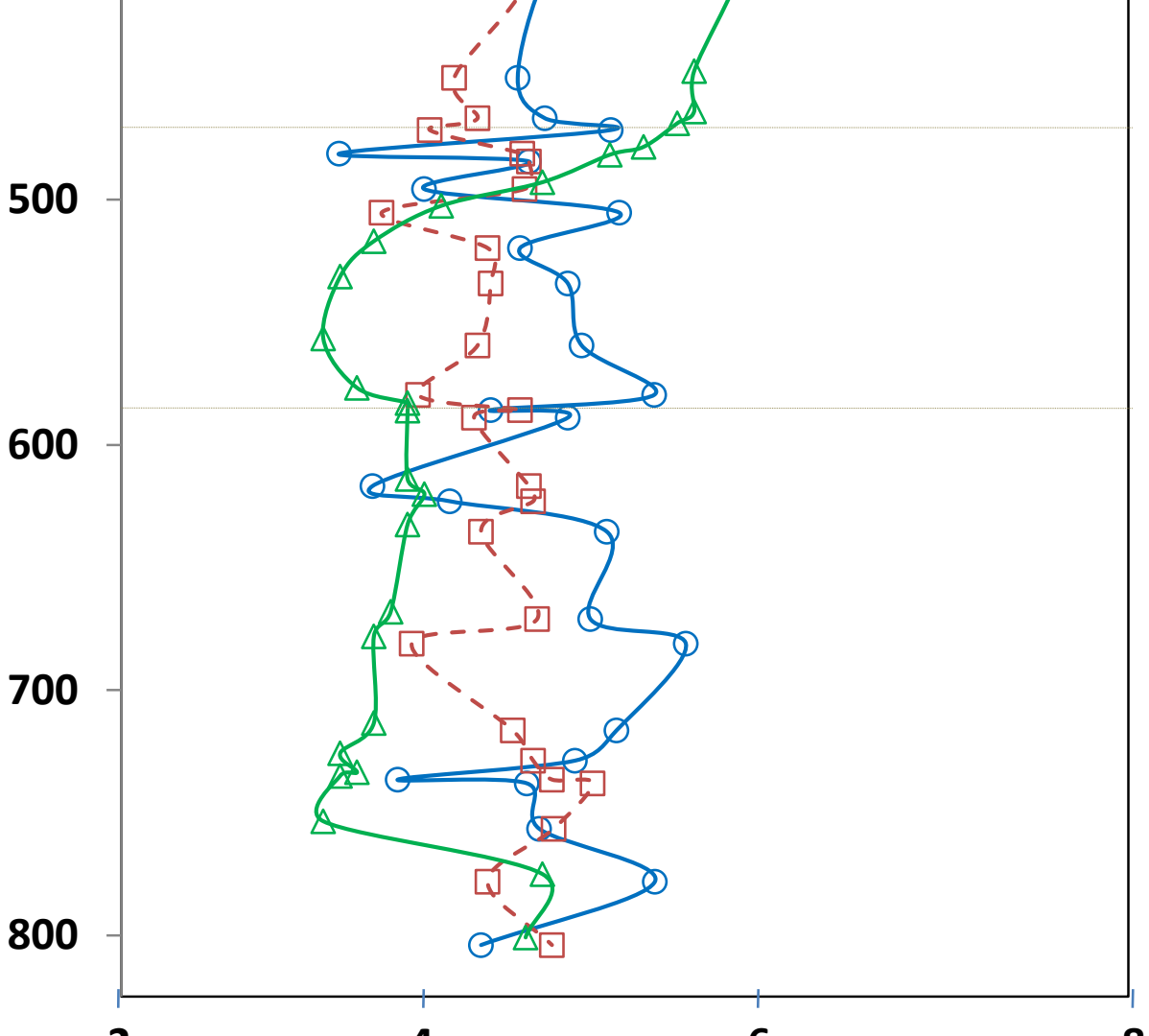

700

800

2

4

6

pH

Figure 3. Description and distribution of $\mathrm{pH}$ and total $\mathrm{U}$ and Th with depth in FW 408. 


\section{Description FW 410}

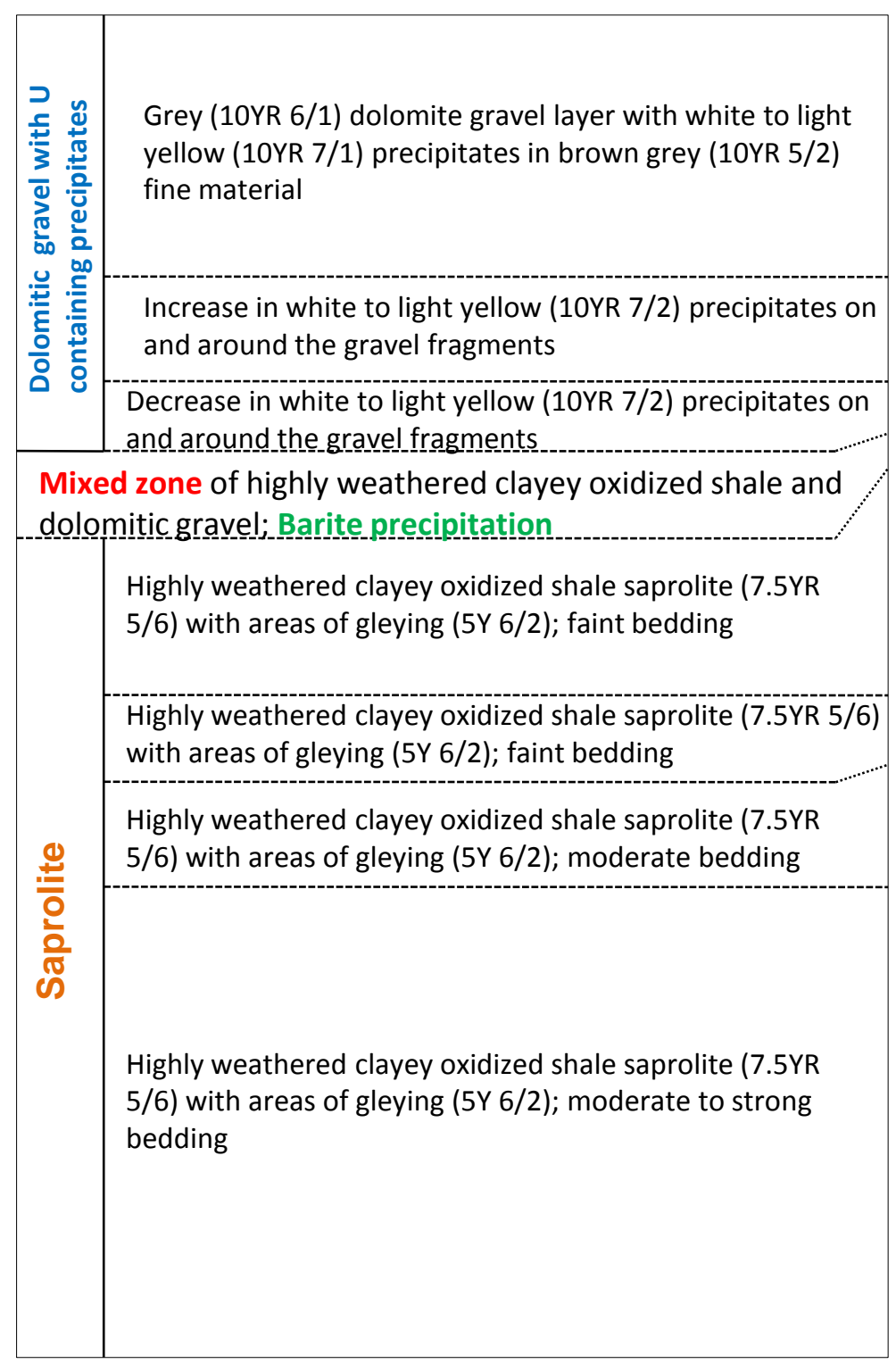

\section{Total U and Th $(\mathrm{mg} / \mathrm{kg})$}

1

10

100

1000

10000

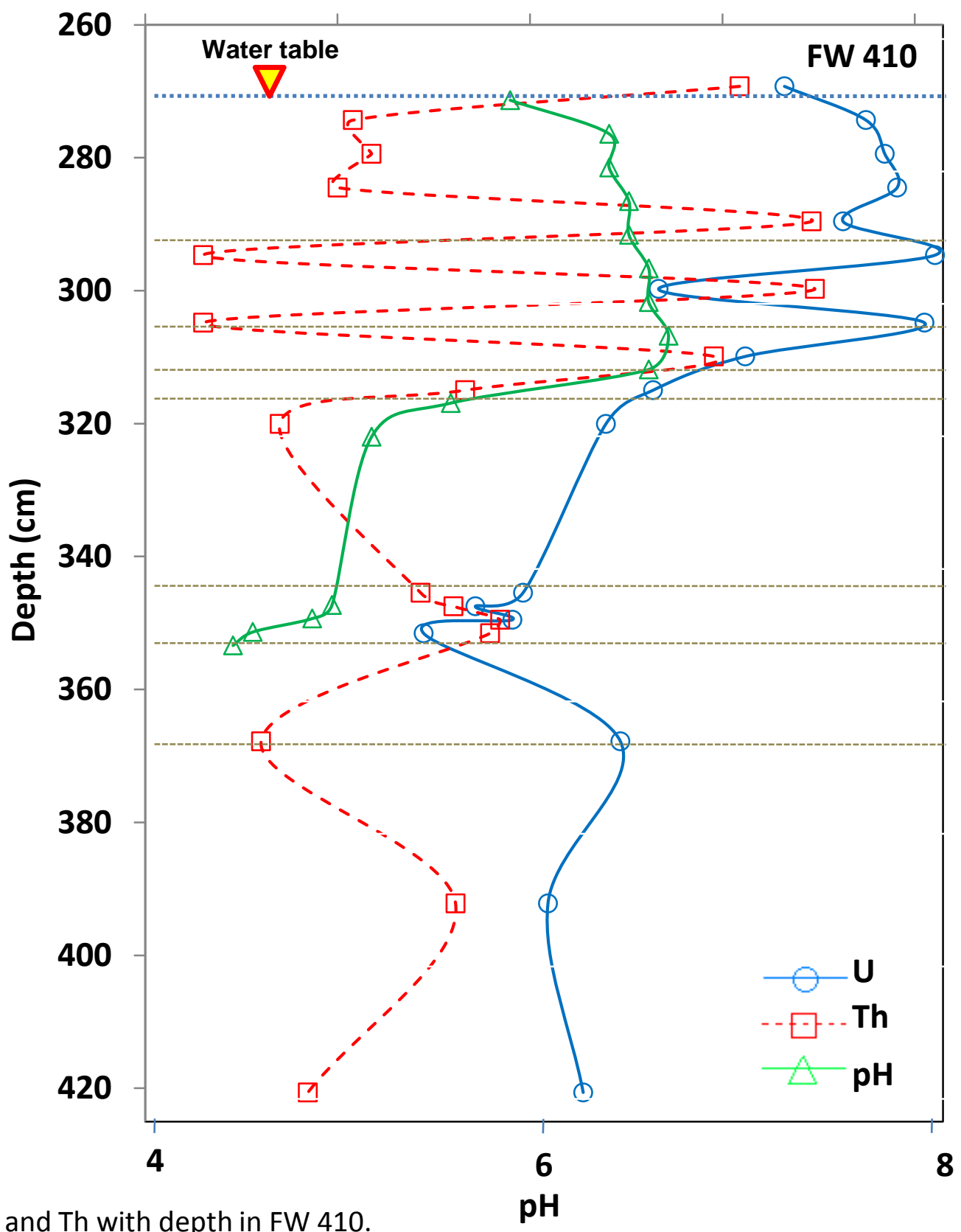

Figure 4. Description and distribution of pH and total $\mathrm{U}$ and Th with depth in FW 410. 


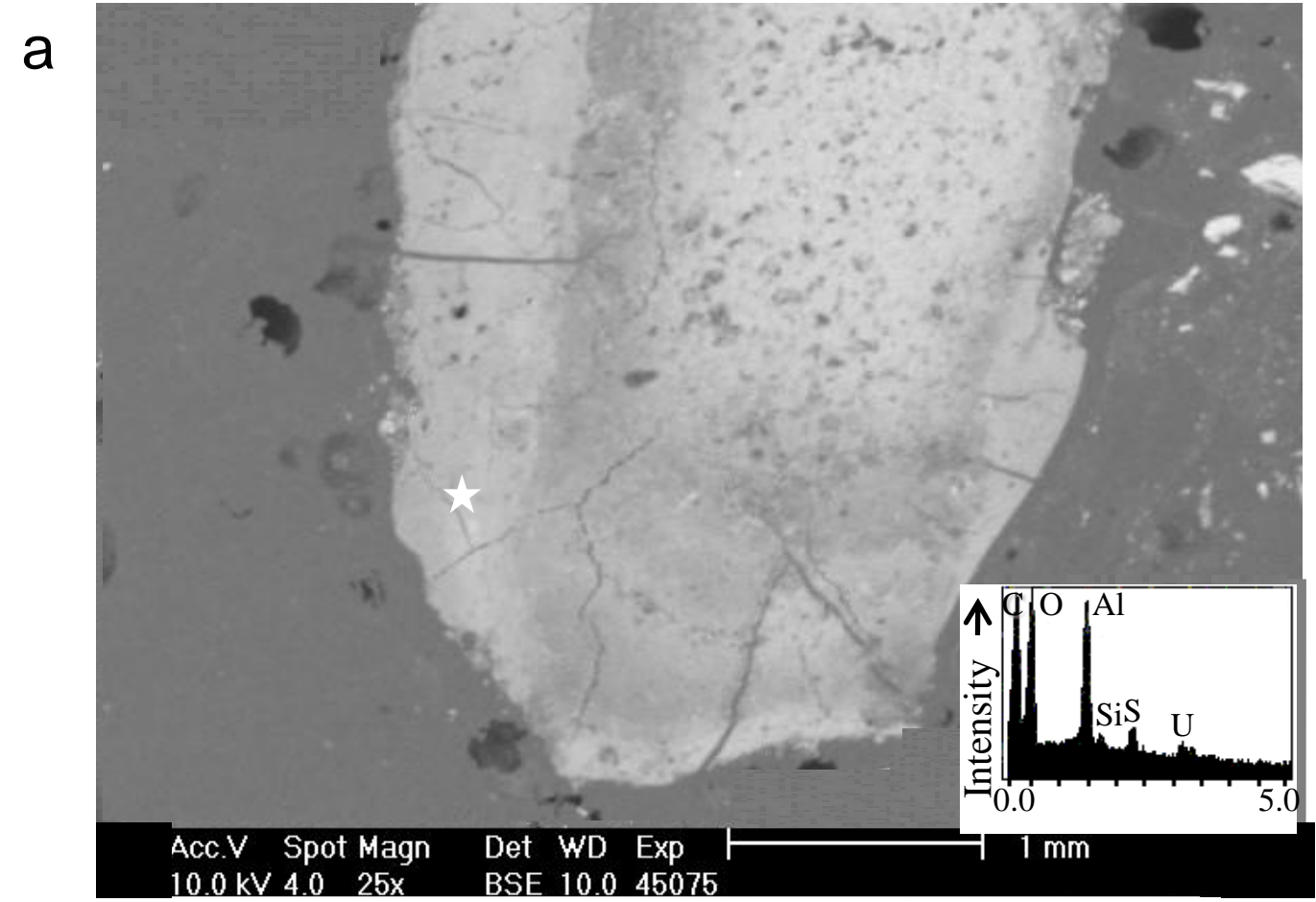

b
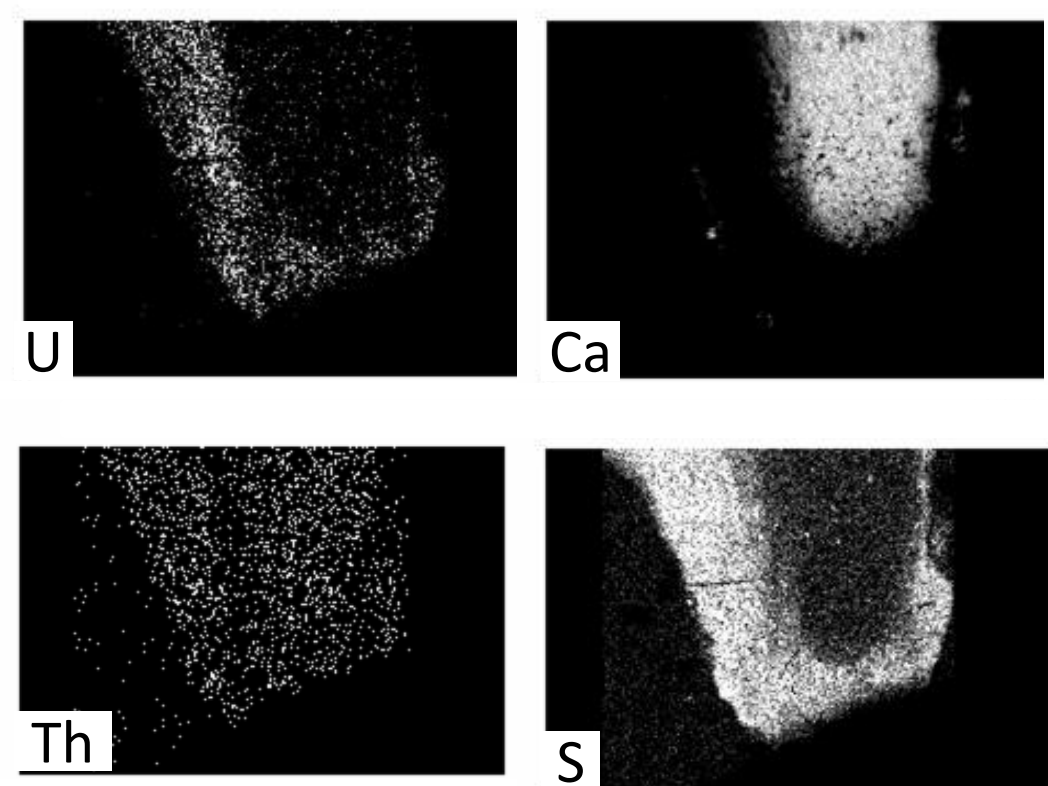
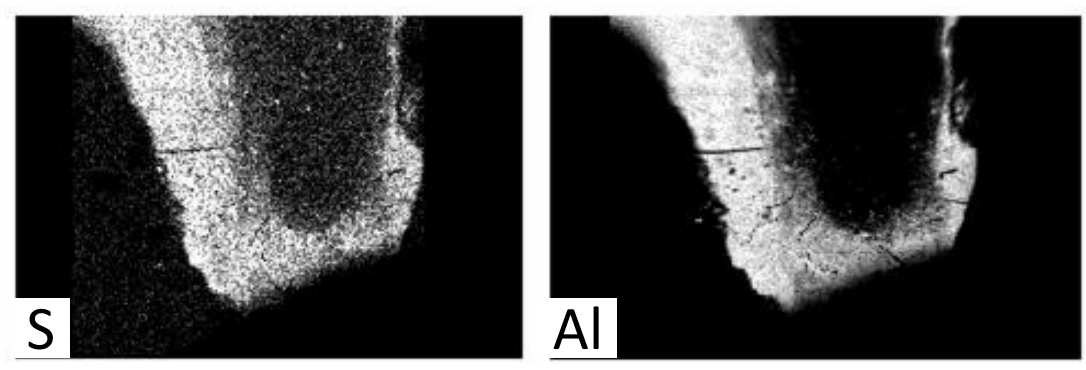

Figure 5. a) SEM micrograph and EDS of a dolomitic gravel fragment with a $U$ containing meta autonite coating, and b) SEM WDS maps of $\mathrm{U}, \mathrm{Ca}, \mathrm{Mg}, \mathrm{Th}, \mathrm{S}$ and Al from (a). 
FW 408
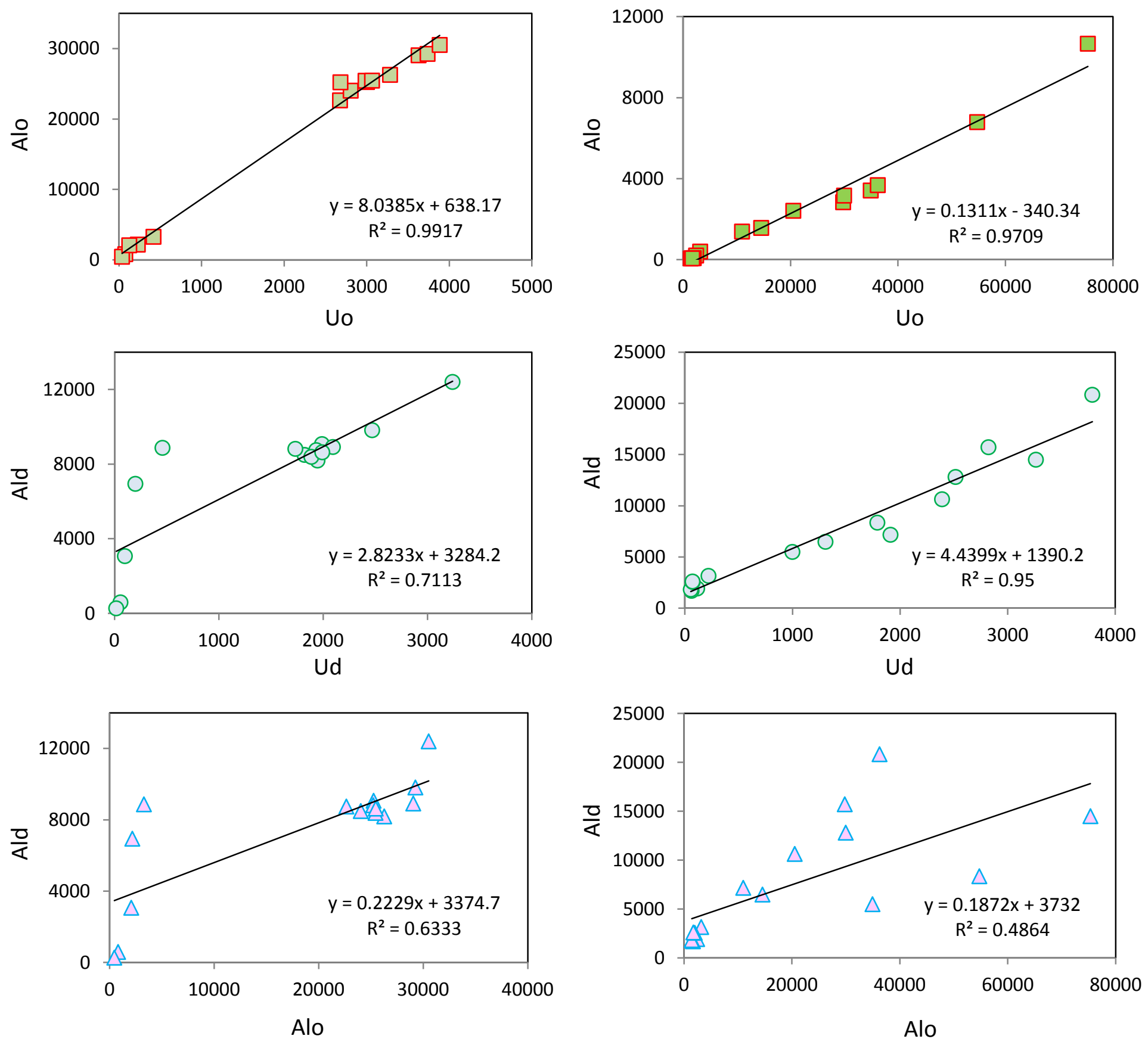

Figure 7. Linear regression of Alo and Uo, Alcd and Ud, and Ald and Alo for the gravel section of FW 408 and FW 410 